\title{
Postcolonial Engagements with the Epics: Multiple and Movable Tectonic Plates
}

\section{Sneharika Roy}

\section{(2) OpenEdition \\ Journals}

Electronic version

URL: https://journals.openedition.org/ces/7855

DOI: $10.4000 /$ ces.7855

ISSN: 2534-6695

Publisher

SEPC (Société d'études des pays du Commonwealth)

\section{Printed version}

Date of publication: 1 September 2011

Number of pages: 25-32

ISSN: 2270-0633

\section{Electronic reference}

Sneharika Roy, "Postcolonial Engagements with the Epics: Multiple and Movable Tectonic Plates", Commonwealth Essays and Studies [Online], 34.1 | 2011, Online since 16 November 2021, connection on 01 December 2021. URL: http://journals.openedition.org/ces/7855 ; DOl: https://doi.org/10.4000/ ces.7855

\section{(c) $(1) \odot$}

Commonwealth Essays and Studies is licensed under a Licence Creative Commons Attribution - Pas d'Utilisation Commerciale - Pas de Modification 4.0 International. 


\section{Postcolonial Engagements with the Epics: Multiple and Movable Tectonic Plates}

This paper investigates the problematic space occupied by the epic, that national narrative par excellence, in an increasingly globalized age. Re-centering the Hegelian conception of the epic as concretizing "the total world of a nation and epoch" towards contemporary theories of globalization allows us to see the global and the local as overlapping plates, perpetually interacting through violent collisions or more complicit coalescences. The specificity of postcolonial epics would therefore seem to lie in their distinctly un-Hegelian configuration of multiple tectonic plates of many nations and many epochs.

Homi Bhabha succinctly sums up the problematics of the global and the local in his essay, "Unsatisfied: Notes on Vernacular Cosmopolitanism" when he asks, "How do we think this relation of locality whose every ebb and flow requires the reinscription of global relations? Where does the subject of global inquiry or injury stand or speak from?" (40). Bhabha's simultaneous focus on inquiry and injury in the context of globalization is crucial, as is his emphasis on the constantly changing relationships of the local, with its ebbs and flows. Indeed, Bhabha sees the local less as a physical entity than as an enunciative space within which the global is being continuously reinscribed. His questions point to the difficulty of nailing down such unstable, fluctuating phenomena, suggesting that equally dynamic paradigms are needed to address these issues. A possible response may be found in the work of Édouard Glissant who baptizes the contemporary configurations of global and local "chaos-monde": "I call Chaos-monde the current clash of so many cultures which ignite, repel each other, disappear, and yet survive, fall asleep or transform, slowly or with lightning speed"' (218). ${ }^{1}$

Both Bhabha and Glissant are concerned with revising the often mutually exclusive categories of the global and the local in relational and reciprocal terms. In doing so, they articulate contemporary concerns in cultural theory and practice which tend to stress notions of identitary flux and interdependence among the parts which ceaselessly reconfigure the whole. James Clifford, for instance, sees contemporary culture as marked by "discrepant cosmopolitanisms" (36), based on a Modernist sense of cultural collage. ${ }^{2}$ Homi Bhabha's "glocal" amalgamate of "vernacular cosmopolitanism," predicated on Judith Butler's idea of "unanticipated

1. "J'appelle chaos-monde le choc actuel de tant de cultures qui s'embrassent, qui se repoussent, disparaissent, subsistent pourtant, s'endorment ou se transforment, lentement ou à vitesse foudroyante" (Tout-Monde 22). Charlotte Girard's translation loses much of the geological, tectonic, thrust of Glissant's images since she translates "s'embrassent" as "ignite" rather than, say, "draw towards each other" or "embrace each other."

2. Clifford proposes a critical reevaluation of the binary of local native/cosmopolitan colonizer, which leads him to the following conclusion: that "certain classes of people are cosmopolitan (travelers) while the rest are local (natives) appears as an ideology of one (very powerful) traveling culture" (36). He points to "diaspora cultures" whose "transplantation" creates forms of "discrepant cosmopolitanisms" involving "dwelling and traveling, traveling-indwelling, dwelling-in-traveling" (36). He finds Modernism particularly useful in its emphasis on collage which he sees as "a way of making space for heterogeneity, for historical and political, not aesthetic purposes" (3). 
transformations" (48), ${ }^{3}$ is another example, as is his notion of hybridization, related to Salman Rushdie's celebration of mongrelization and Caribbean patterns of métissage. Another highly dynamic model can be found in Antonio Benítez-Rojo's application of the chaos theory to the Caribbean context of carnival, closely linked to subversive Bakhtinian dialogism. To return to Glissant's analysis of the totality and the relation which are renegotiated towards a non-totalizing chaos-monde, one discerns hints of geological overtones in the critic's insistence on the gradual or split-second clash of cultures which are drawn together, drawn apart, still subsist or are transformed. In fact, Glissant prompts us to see cultures as tectonic plates in a state of perpetual flux, converging and diverging, sometimes disappearing on the top but subsisting below. Glissant has a metatextual penchant for geological metaphors particularly in later works such as Ormerod:

It is said, with the certainty of sciences and prophecies, that very soon, tomorrow, a monstrous scraping together of plates in the depths will unleash - like shattered shards of a writing that seethes with rage and mutilates itself - the apocalypse which will swallow these lands and submerge the sea itself, in a fury of tides beyond scale or intention, and of winds bereft of direction. ${ }^{4}$

Taking this further, one may say that there is a paradigm of cultural tectonics at work, one which resonates with contemporary discourse of fragments and the whole, collage and métissage, chaos theory and unanticipated transformations mentioned earlier. What emerges is a theory of transcultural tectonics. Here, binary definitions of the global totality against the local detail are discarded in favour of a more dynamic framework where both become floating plates, enunciative planes of "inquiry" and "injury," to use Bhabha's twin terms, perpetually interacting through violent collisions or more complicit coalescences.

If Glissant is to be the source of this paradigm of cultural tectonics, it would be worthwhile to recall that he counterpoints chaos-monde with what he calls a "poetics of relation": "And I call poetics of relation, this potential of the imagination that leads us to consider the ungraspable globality of this kind of chaos-monde at the same time that it helps us to pick out details, and in particular to sing of our place" (Prieto 117). ${ }^{5}$ Glissant situates what he sees to be the specifically postcolonial preoccupation of "sing[ing] of our place" at the heart of these reconfiguring, overlapping relationships between the global and the local force-fields. This conception of singing one's place recalls the generic prerogative of the epic, that national narrative par excellence, which as Hegel put it, transforms an isolated "action into a rich event connected with the total world of a nation and epoch" (1044). Notice the use of the singular: it is one nation,

3. Bhabha quoting Judith Butler's "Kantians in Every Culture?" in Boston Review XIX.5 (Oct/Nov 1994): "She writes: 'The movement of the unanticipated transformation establishes the universal which is yet to be achieved and which in order to resist domestication may never be fully or finally achievable'." (48).

4. In the absence of a published English translation of Ormerod, I hazard the above translation of the following: "Il est dit, de science et de prophétie certaines, que bientôt, demain, un monstrueux raclement des plaques d'en dessous provoque - comme une écriture cassée concassée qui d'elle-même s'emporte et se meurtrit - l'apocalypse qui engloutit ces terres et submerge la mer elle-même, dans une furie d'eau sans dimension ni intention, et de vent sans direction" (16). I would like to thank Madeleine Laurencin and Vincent Bucher for their suggestions.

5. Eric Prieto, in his article on Glissant, offers the above translation for this key-quote from Traité du tout-monde: "J'appelle poétique de la relation ce possible de l'imaginaire qui nous porte à concevoir la globalité insaisissable d'un tel Chaos-Monde, en même temps qu'il nous permet d'en relever quelque détail, et en particulier de chanter notre lieu” (22). 
suspended in one epoch that the epic fixes in cultural memory. From this angle, Glissant's originality lies in his contestation of the centripetal, totalizing tendencies of the epic in favour of a more globalized, centrifugal one, based on diversity and rhizomatic errantry. Put another way, Glissant challenges centripetal pulls towards an imperial centre which characterize epic narratives such as The Aeneid where Virgil's bard sings of "the long glories of Majestik Rome" (3). Camoens, in his epic invocation in The Lusiads, celebrates the Portuguese expedition undertaken by Vasco Da Gama and his "hero-band" who "should span the pathless deep, and [...] / Should with new victo'ries eve'ry deed out-dare” (15). A strong centripetal pull is also palpable in Walt Whitman's Leaves of Grass in which the bard proclaims, "Thou Union, holding all, fusing, absorbing, tolerating all, / Thee, ever thee, I sing” (203).

Postcolonial engagements with the epic also re-position the nation at the centre of narratives that sometimes tend towards totalization. Shashi Tharoor's narrator in The Great Indian Novel aspires to recite nothing less than the "Song of Modern India," singing of "past, present and future, of existence and passing, of efflorescence and decay, of death and rebirth" (18). Pablo Neruda sees Canto General as his "Common book of mankind" which anchors a common Latin American identity in peasant struggles and populismo. He thus proposes an epic where "broken bread / is this geography of my song, / and a community of peasants / will one day harvest its fire" (399). Finally, Derek Walcott in Omeros retrospectively describes his poetic project thus, "I sang our wide country, the Caribbean Sea" (320), widening the reach of his small island home through intertextuality, in much the same way James Joyce did for Ireland in Ulysses. However, Walcott, Tharoor and Neruda exhibit a critical awareness of the weaknesses of epic projects, whether imperial or nationalist. They do so by embracing a certain openness to the role played by global forces of colonization as well as resurgent ethnicities in the shaping of present postcolonial identities. As much as they are writing back to the empire, they are also writing back to the flawed postcolonial nation. These narratives are marked by an acute awareness that when a new continent emerges, there are always fissures within and without, making it impossible to isolate global and local phenomena in tidy compartments. As Bhabha points out, the global that existed beyond the local is now indelibly re-inscribed within the local, so much so that Glissant can say that the "Antilles have become the estuary of America" (Discours 427) and Neruda, that "At the bottom of America without name / was Arauco among the vertiginous / waters" (26).

What we have here is a shift from what Glissant calls "the excluding epic," an insular mode grounded in ancestral legitimacy, violence and the universalization of a single culture, ${ }^{6}$ towards "the participatory epic" which favours involvement in the world-community and redefines universals in terms of "the finite and infinite quantity of all cultures and all humanities" (222). ${ }^{7}$ Glissant re-centers the traditional genre-

6. Glissant explains "the excluding epic, of yesterday or of days long past, from the time when human communities conceived of themselves in ethnic and almost genetic terms, as much as by the 'universality' of their individual cultures” (221-2). This is a translation by Barbara Lewis of Glissant's Faulkner, Mississippi. The original text reads thus: "l'épique excluant, hier ou jadis, au moment où les communautés humaines se concevaient par l'éthique et presque par le génétique, tout autant que par l'« universel » de chacune de leurs cultures" (Faulkner, Mississippi 303).

7. The English translation elides an important semantic distinction in French between the substantive (épopée) and the adjective (épique) through the use of the same morphological form, epic, for both grammatical categories. Glissant by privileging the more open épique is moving away from a genre-based anatomy of criticism towards a postcolonial 
based epic problematic in political, contrapuntal terms of mythic purity versus lived hybridity, ancestral filiation versus imaginative affiliation, a narrative of legitimacy versus a narrative of self-reflexive irony. The poetics of participatory epics represents a postcolonial theorization of contemporary cultural practices which write back to and de-center the Hegelian conception of the epic as crystallizing "the total world of a nation and epoch." The emphasis on ethics, finite and infinite humanities rather than on the national/international dialectic is also illuminating. If the excluding, foundational epics reflect a cultural tectonics of mutually exclusive, fixed continental plates, the participatory, relational epics, as products of a hybrid, globalizing world, seem to embrace a world-system of overlapping, multiple and movable tectonic plates.

Despite its merits, the paradigm Glissant proposes is still a somewhat polarized one (Old World = excluding epics $/ \mathrm{New}$ World = participatory epics). Within this scheme, the United States of America occupies a problematic, chiasmatic space as both colonized and colonizer, criss-crossing between the two positions and consequently producing epics that straddle the excluding and the participatory. As part of the New World but also a colonizer of regions of Asia and Central America, the United States both confirms and contests this bipartite distribution. Glissant's distinction would therefore gain further depth were we to see the excluding and participatory epics as both convergent and divergent, drawing towards and away from each other at the same time. The New World epics that spoke for the age were not imitative Homeric verse-epics of Hartford Wits such as Timothy Dwight's The Conquest of Canäan (1785) and Joel Barlow's Columbiad (first published as The Vision of Columbus in 1787), modelled on the stylistic conventions of exclusionary epics. The New World spirit of the emerging nation seemed to be captured in the more novelistic, transcultural works of Walt Whitman and Herman Melville who move towards relational, participatory epics. That said, the emerging American political and cultural hegemony is evident in Whitman's verse and perhaps best exemplified by his penchant for lists, binding diversity within a single federal unity. It has often been pointed out that the epic bard who claims to be "large" and "contain multitudes" ("Song of Myself" 86) becomes a synecdoche of America, "the Great Nation, the nation of many nations" (44). His famous poem, "Passage to India," is a condensed epic in itself, mid-way between a Camoensesque celebration of the expeditions of Alexander, Marco Polo, Columbus and Da Gama, and a prophetic ode to globalization, to "The earth to be spann'd, connected by net-work" (412). Yet despite the proclamation of "the marriage of continents, climates and oceans," hierarchical binaries persist as America is glorified as the New World, as opposed to the Old World, which itself is represented by an indiscriminate clubbing together of "Europe, to Asia, Africa, join'd" (416).

Against a vague Oriental backdrop of “Asia's, Africa's fables," a detailed American cartography emerges through enumeration as the poet admires "my own continent [...] the grandest scenery in the world": from the Pacific Railroad winding along the Platte to Monument mountain and the Laramie plains, down to the "plentiful larkspur

hermeneutics grounded in hybridity and political agency. Apart from this important detail, Barbara Lewis' and Thomas Spear's translation remains faithful to the original: "l'épique concluant est participant qui mènerait la communautémonde, aujourd'hui, à paraître, et où l'« universel » serait bien la quantité finie et infinie de toutes les cultures et de toutes les humanités" (303-4). 
and wild onions" (413). This unity in diversity is emphasized both on a national level (America as a federation) and an international, even cosmic level through a transcendental vision of "one-Soul." This is accomplished in a Miltonian gesture wherein "The whole Earth [...] shall be completely justified [...] by the son of God, / the poet" (415). While Allen Grossman wrote in 1985 that Whitman's verse was marked by "pluralization (the getting of many into one) without the loss entailed by the exchange" (qtd. in Moretti 191-2), contemporary readers might be inclined to feel that there is indeed a loss or, at least, a lack of exchange: the epic remains a national narrative which, though opening itself to other cultural horizons, still favours a centripetal focus on the nation as a microcosm of the global. This remains a one-way traffic of ideas rather than an exchange or cross-fertilization of cultures.

This should, nonetheless, be put into historical perspective. Given the context in which the poem was produced, "Passage to India" (first published in 1871) offers a multicultural vision in a massively colonized era, marked by the Scramble for Africa, the British Raj in India and the plantation systems in America and the Caribbean. From this perspective, Whitman and Melville stand at the crossroads between teleological and relativizing cultural perspectives, or, to use Glissant's geological terms, "continental" and "archipelago" worldviews. In Tout-monde, Glissant argues that the thick continental thought-system weighs down on us by virtue of its teleological conception of the humanities, a conception no longer suited to contemporary history, with its dispersions and "sumptuous wanderings." Contemporary cultural theory for him is that of the "archipelago," for "the world has been dispersed into archipelagos of diversities" (31).

The archipelago thought-system seems particularly fruitful in the context of the "sumptuous wanderings" Pound, Pablo Neruda or Saint-John Perse, Salman Rushdie or Derek Walcott. Indeed, a Glissantian reading of The $W$ aste Land might reveal how the continental thought begins to break up into mobile archipelago-like scraps of texts from Greek and Arthurian legend, Shakespeare, Dante and the Bhagwad Gita, all of which appear to the narrative consciousness as "fragments I have shored against my ruins" (Eliot 79).

Fragmentation, disintegration and ruins are a poignant reminder that cultural tectonics not only involves overlapping reciprocity and exchange but also destruction and even at times, total annihilation. A case in point is that of deculturation and the disappearance of local cultures during cataclysmic colonial and neo-colonial confrontations. This is perhaps most glaring in the loss of the sense of the local in the Caribbean context. In the West Indies, colonization went hand in hand with an uprooting of indigenous culture, a fact Derek Walcott conveys powerfully in the incipit of Omeros. He does so by using the extended metaphor of the epic slaughter of

8. In the absence of a published English translation of Glissant's Tout-monde, I hazard the following translation: "The idea of the archipelago is in step with the rhythm of our worlds [...]. In the sumptuous thought systems which till today governed the History of humanities and which are no longer adequate for our explosions, neither for our histories nor for our no less sumptuous errances, we recognize something heavy, continental and thick, which weighed us down. The idea of archipelago, of archipelagoes, opens up these seas for us." In Glissant's own words: "La pensée archipélique convient à l'allure de nos mondes [...]. Nous nous apercevons de ce qu'il y avait de continental, d'épais et qui pesait sur nous, dans les somptueuses pensées de système qui jusqu’à ce jour ont régi l'Histoire des humanités, et qui ne sont plus adéquates à nos éclatements, à nos histoires ni à nos moins somptueuses errances. La pensée de l'archipel, des archipels, nous ouvre ces mers" (Tout-monde 31). 
the cedar trees, linked to the mythological "first god [who] was a gommier" (5). ${ }^{9}$ The Caribbean thus appears to be a potential cultural wasteland, a potentiality that V. S. Naipaul saw as a reality when he emphasized stingingly that "nothing has ever been created in the West Indies" (29). Walcott's transcultural counter-strategy lies in indiscriminately gathering the fragments of pre-colonial West Indian culture (for example, African and Arawak gods) as well as acculturated elements of the Occident (anything from Homer and Dante to the Beatles). He thus moulds a new aesthetic and cultural artefact, in much the same way the Caribbean fishermen cut the trees to build canoes, and earn their livelihood.

Walcott's epic thus rings an avowedly "conciliatory" note of "sumptuous wandering" in lieu of imperial founding and settlement. In a much neglected passage in Omeros, Achille, a simple fisherman, thinks of fleeing the island with its "hotels, marines and $[\ldots]$ pink tourists" in order to "find some place [...] he could settle like Aeneas, founding not Rome, but home, to survive in its peace" (301). The paronomastic association of Rome and home differentiates and blurs the global and the local at the same time. This is reinforced by the simultaneous use of "like," creating similarity, and "not," marking difference in the line that follows, showing that the text is both attracted towards, and repelled by the Aeneid and the centripetal pull it represents: indeed, the more transcultural parallels it establishes, the more indigenous differences it brings to the surface. Glissant articulates this double dynamic of indigenous and global, each redefining and undermining the other in a state of perpetual tension when he says,

Yes, we are just barely beginning to conceive of this immense friction. The more it works in favour of an oppressive order, the more it calls forth disorder as well. The more it produces exclusion, the more it generates attraction. It standardizes - but at every node of Relation, we will find callouses of resistance." (Poetics 138) ${ }^{10}$

In Walcott's transcultural, intertextual universe with its "Greek manure under the banana leaves" (271), Greco-Roman antiquity and Caribbean lived experience incessantly fuse into and fertilize each other: Achille the Caribbean fisherman is likened to Aeneus the high-born Trojan prince, who, we must recall, was himself "Expell'd and exil'd [...] before he won / The Latian realm, and built the destin'd Town" (3). In this sense, Aeneus, seen synchronically through the prism of Achille the Caribbean fisherman (and not the other way round), also becomes a temporary victim of conquest, a migrant-figure not unrelated to Ulysses, perhaps the proto-type of the diasporic subject, "Expell'd and exil'd." However, Achille's goal is not aggressive colonial resettlement, but is based on the pragmatic live-and-let-live philosophy of the

9. The discrepant association between the cedar trees and the gommier can be explained by the fact that the incipit is filtered through a narrative consciousness that incessantly oscillates between past and present, between epic memory and the Caribbean postcolonial present. Thus when the fisherman Philoctete begins cutting down cedar trees, the narrative consciousness recasts this prosaic activity as an epic "sacrifice," retracing the erasure of the Aruac culture with its pantheistic gods ("The first god was a gommier") by European colonizers. The link between the cedar and the gommier is therefore associational and imaginative, allowing the narrator to cross the "pause that lasted for centuries" (5) between pre-colonial Aruac settlement and European colonization with its attendant conversion to "a single God where the old gods stood before" (5).

10. "Oui, nous commençons à peine de concevoir ce gigantesque frottement. Plus il concourt à un ordre oppresseur, plus il suscite aussi de désordre. Plus il produit de l'exclusion et plus il génère de l'attraction. Il standardise - mais à chacun des nœuds de la Relation nous trouverons des cals de résistance." (Poétique 153) 
oppressed postcolonial subject, deprived of agency in a neo-colonial world of standardization, of "hotels, marines [...] and pink tourists."

We will never know whether Achille will really find a home untainted by neocapitalist forces in much the same way as we will never know whether Walcott's lyrical persona will ever stop seeing "All that Greek manure under the banana leaves." What we do know, however, is that neither one can be seen in isolation without the other. The relationship between the two, an obscure fisherman whose way of life is profoundly endangered and the renowned Nobel Prize-winning poet, is representative of the contradictory yet co-existing and co-producing forces of marginalization and elitism. Rather than polarizing them, one may see these phenomena as interacting problematically, reinforcing and undermining indigenous and international enunciative spaces. The cultural tectonics unleashed by globalization suggests universalizing, macro-processes as well as the interstices between the plates, where, to use Bhabha's terms, we find the simultaneous self-construction of the individual as the "subject of global inquiry" and of "injury." The texts of Walcott, Tharoor, Neruda, Joyce and others crystallize the chaos-monde of cultural tectonics because they foreground local positions from which inquiries and injuries may be articulated through their relation to this "earth to be spann'd, connected by net-work," as Whitman put it. More precisely, rather than being "spanned," the earth can now only be inscribed in localized songs of place. From this angle, the specificity of New World epics would lie in their projected cartographies of a distinctly un-Hegelian configuration of multiple and movable tectonic plates of many nations (or Glissantian "places") and many epochs

Sneharika ROY, Université Sorbonne Nouvelle - Paris 3

\section{Works Cited}

Benitez-Rojo, Antonio. The Repeating Island: The Caribbean and the Postmodern Perspective. Trans. James E. Maraniss. Durham: Duke UP, 1992.

BARLOW, Joel. The Vision of Columbus, a Poem in Nine Books. Hartford: Hudson and Goodwin, 1787.

BнавнA, Homi. "Unsatisfied: Notes on Vernacular Cosmopolitanism." Postcolonial Discourses: An Anthology. Ed. Gregory Castle. Oxford: Blackwell, 2001. 39-52.

CAmoens, Luís. Os Lusiades (The Lusiads). Vol. 1. Trans. Richard Francis Burton. London: Tinsley, 1880.

CLIFFORD, James. Routes: Travel and Translation in the Late Twentieth Century. Cambridge, MA: Harvard UP, 1997.

Dwight, Timothy. The Conquest of Canäan. Westport: Greenwood, 1970.

ELIOT, T. S. “The Waste Land.” Collected Poems 1909-1962. London: Faber, 1983. 61-80.

GLISSANT, Édouard. Le discours antillais. Paris: Seuil, 1981.

-. Faulkner, Mississippi. Paris: Stock, 1996. Trans. Barbara Lewis and Thomas Spears. Faulkner, Mississippi. Chicago: U of Chicago P, 2000.

—. Ormerod: roman. Paris: Gallimard, 2003.

-. Poétique de la relation. Paris: Gallimard, 1990. Trans. Betsy Wing. Poetics of Relation: Édonard Glissant. Ann Arbor: U of Michigan P, 2006.

-. Traité du tout-monde. Paris: Gallimard, 1997.

GIRARD, Charlotte. "Contracting and Founding in Times of Conflict." Varieties of World-Making: Beyond Globalization. Ed. Nathalie Karagiannis and Peter Wagner. Liverpool: Liverpool UP, 2007. 216-31.

Hegel, G. W. F. Aesthetics: Lectures on Fine Art. Vol. 2. Trans. T. M. Knox. Oxford: Clarendon, 1975.

JOYCE, James. Ulysses. 1922. Oxford: Oxford UP, 2008.

MoreTTI, Franco. Modern Epic: The World-System from Goethe to García Márquez: Trans. Quintin Hoare. London: Verso, 1996. 
Naipaul, V. S. The Middle Passage: Impressions of Five Societies - British, French and Dutch - in the West Indies and South America. London: Deutsch, 1962.

Neruda, Pablo. Canto General. 1950. Trans. Jack Schmitt, based on $2^{\text {nd }}$ ed. (Caracas: Biblioteca Ayacucho, 1981). Berkeley: U of California P, 2000.

PrieTo, Eric. "Édouard Glissant, Littérature-Monde, and Tout-Monde." Small Axe 33 (November 2010): 111-20.

THAROOR, Shashi. The Great Indian Novel. New Delhi: Penguin, 1989.

VirgiL. Virgil's Aeneid Translated by John Dryden. Trans. John Dryden. Ed. Frederick M. Keener. London: Penguin, 1997.

WALCOTT, Derek. Omeros. New York: Farrar, 1992.

Whitman, Walt. Leaves of Grass. Ed. Sculley Bradley and Harold W. Blodgett. New York: Norton, 1965. 